\title{
OCCURRENCE OF WOOD-AND ROOT- ROT BASIDIOMYCETES ON TREES IN BAYERO UNIVERSITY, KANO, NIGERIA
}

\author{
${ }^{1}$ Kutama*, A. S., ${ }^{2}$ Saratu, A.O. and ${ }^{3}$ Asma'u, A. U. \\ ${ }^{1}$ Department of Plant Science, Bayero University, Kano - Nigeria \\ ${ }^{2}$ Department of Science Laboratory Technology, Kano State Polytechnic, Kano - Nigeria \\ ${ }^{3}$ Department of Biology, Federal college of Education, Kano - Nigeria \\ *Correspondence author: kutamasak@yahoo.com
}

\section{ABSTRACT}

Several death and decays or rots of tropical trees are as result of infection caused by wood and root rot 'parasitic basidiomycetes. In the present study, survey of parasitic homobasidiomycetes causing wood and root rot on woody trees in Bayero University, Kano (two campuses) was carried out between April - September, 2011. The survey was conducted in two phases, to determine the occurrence of wood and root-rot parasitic fungi on the trees and the level/extent of damage done by the parasites. Results on the distribution and relative abundances of these wood and root-rot causing parasitic basidiomycetes have indicated the presence of two predominant species: Ganoderma phillipii and Phellinus noxious on the trees found on the two campuses with Ganoderma phillipii being the most occurring (40 and 15 isolates from old and new campus, respectively) while Phellinus noxious was the least (31 and 17 isolates from old and new campus, respectively). These parasitic basidiomyecetes were found affecting and causing damages on Azadirachta indica (neem tree) and Parkia biglobosa (parkia) trees. A total of 22 trees (seven and 15 in the old and new campus, respectively) were found dead due to serious infection by the parasites. This situation if left unchecked may grow and become a more serious threat to the trees on the two campuses. Effort should be made to eliminate these fungi before they kill more of the trees on the two campuses considering the importance of trees to mankind.

Keywords: Basidiomycetes, woody trees, Bayero University, wood and root rot

\section{INTRODUCTION}

The basidiomycetes comprise of an assemblage of the most advanced group of fungi whose members include the popular mushroom, Toadstools, Puffballs, bracket (shelf) fungi, rusts, and smuts (Mehrotra and Aggarwal, 2003; Kutama, 2011). They reproduce sexually by means of exogenously produced basiodiospores (Hood. 2003, 2006). Basidiomycetes belong to the phylum division basidiomycota, with about 31, 515 species from 1, 589 genera (Hood, 2003). The division was traditionally divided into two old classes, namely; homobasidiomycetes (comprising of mushrooms, and bracket fungi) and heterobasidiomycetes (including jelly fungi, rusts and smuts) (Tarr, 1962; Moore, 2006; Norman et al., 2008). Basidiomycetes are mostly saprophytic, surviving on decayed organic substrates but very few are obligate parasites. Of the two classes of basidiomycetes mentioned, the homobasidiomycetes cause important tree diseases in the tropical world. Example of parasitic species of homobasidiomycetes belongs to two important genera: Ganoderma and Phellinus noxious. Ganoderma is a genus of polyspores which grow on woody tree (Hood, 2006). These parasitic basidiomycetes cause decomposition of wood resulting into a whitish coloration of the dead wood popularly known as white rot. Wood and root rot basidiomycetes are occasional problem in desert plants including cliff rose, Canotia (Canotia holacantha) e.t.c (P.D.P, 2011). Also cacti which have a large amount of solid wood tissues may be invaded and decayed by wood rotting basidiomycetes (Uno et al., 2008).

Trees are a very important natural component of the environment that help to produce and re-cycle fresh air, provide habitat and food for man, animals and plants. Trees also provide an anitidote against erosion. They are sources of so many important medicaments. Perhaps, the importance of trees can not be over emphasized. Because of the innumerable economic importance of trees to humanity, their conservation of at least protection is of paramount importance to mankind. However, many death and decays of tropical trees and due to infection by several species of wood and root - rot basidiomycetes. There is the apparent need to conserve these trees. So many governmental as well as voluntary organizations are advocating for the conservation of our trees as well as re-planting them where necessary. This call for the need to continuously make up-date on the occurrence of any factor that might lead to the destruction of these valuable natural gifts, the trees. The aim of this study was to investigate for the occurrence of wood and root-rot causing basidiomycetes on trees in two campuses of Bayero University, Kano. 


\section{MATERIALS AND METHODS Study site}

The study was carried out in the old and new campuses of Bayero University, Kano located on the co-ordinates; latitude $12^{\circ} 04^{\prime} \mathrm{N}$, longitude $7^{\circ} 32^{\prime}$ and on an average elevation of $573.3 \mathrm{~m}$ above sea level. The University campuses are located in the Sudan savanna region of Nigeria.

\section{Field survey and sample collection}

The survey was done between April to September, 2011 in two phases; first and second phase. During the first phase, only infected trees or trees bearing the sporophore fruiting body of the parasitic fungi were inspected, identified and marked. The specific locations of such trees, their number as well as the level of damage on the trees were also noted. Samples of the fungi were obtained using sharp, strong and sterilized blade or knife from the site of infection; trunk or root base (Steyaert, 1967). Each sample was labeled and packed in a sterilized polythene bag and quickly taken to the laboratory for identification. During the second phase, other trees on the two campuses were surveyed to identify the tree species, location, presence or absence of any fungal growth and symptom of infection. Trees around the school premises and staff quarters were both surveyed. A total of 618 trees were surveyed in the first and second phase of the survey on both campuses.

\section{Method of identification}

The various samples of the parasitic basidiomycetes collected during the survey were identified in the laboratory based on macroscopic features as described by Uno et al. (2008) and Corner (2001). Macroscopically, Ganoderma sp has a fruiting body with a broadly attached, wood shelf, smooth, semi glossy in part, colored dark reddish or purplish brown with fine pores, $4-7$ per millimeter. On the other hand, Phellinus noxious has a fruiting body with a brown, broadly attached woody shelf developing blackish crust on the upper surface, grayish to dark brown fine pores $6-8$ per millimeter (Hood,2003; 2006; Old et al., 2000; Galdigil et al., 2005),

\section{Data analysis}

Paired t- test was adopted to statistical compare the distribution of the various parasitic basidiomycetes on the two campuses of Bayero University, Kano.

\section{RESULTS AND DISCUSSION}

The distribution and relative abundances of various parasitic basidomycetes on woody trees in the two campuses of Bayero University is shown in Table 1. A total of 103 parasitic basidiomycetes were obtained during the survey. In the old campus, 71 isolates were identified out of which 40 belongs to Ganoderma phillipii while 32 were Phellinus noxious (Figure 1). However, in the new campus, only 32 isolates were obtained, despite the larger number of the trees on campus (Table 2), out of which 17 belong to Phellinus noxious and fifteen isolates were Ganoderma phillipii. This indicates that there were more parasitic basidiomycetes on B.U.K old campus trees than on new campus trees. T-test at $5 \%$ probability level indicates a significant difference $(P \leq 0.05)$ between the two sites. The large number of parasitic basidiomycetes from old campus trees might be due to two reasons; firstly, most of the trees in the old campus are older than those of the new campus, and secondly, due to narrow size of the old campus, trees are being cut or occasionally wounded. Uno et al. al. (2008) reported that in living trees and shrubs, most rotting caused by parasitic basidiomycetes are confined to the older central wood of stems and branches. They added that the conks of these fungi appear near the infection sites. Nunez and Ryvarden (2005) explained that the shelf - shaped fungal structures of parasitic basidiomycetes are commonly seen along the main trunk and on infected branches. The fungus enters through wound and the disease progresses slowly and is generally not noticed until the fungus has destroyed the heart wood. The number of infected tree plants in the two campuses also differs. Table 2 shows the distribution of the various tree plants affected by the parasitic basidiomycetes. In both campuses, three plant species appeared to be the predominant trees; Azadirachta indica (Neem), Parkia biglobosa (parkia) and Mangifera indica (Mango). In the old campus, sixty one, 10 and zero isolates of parasitic basidiomycetes were found on Neem, parkia, and Mango tress, respectively, while in the new campus, 25 , six and one isolates of parasitic basidiomycetes were recovered on Neem, parkia, and Mango trees, respectively. The results has clearly shown that in both old and new campus neem and parkia trees were having the largest number of wood and root rot causing fungi while mango was having the least. However, despite their number, the level of damage done by the parasites (Table 3 ) was relatively insignificant but may be progressive with time. This was probably because the parasitic basidiomycetes find it relatively hard to attack and decompose the trees because the trees possess hard body and bark making it tough for parasitic fungi to cause considerable damage (Corner, 2001). Some parasitic fungi such as Ganoderma sp were therefore confined to roots (Figure 2), thereby causing root rot. The two species of parasitic basidiomycetes recovered during the study period are the most common causes of wood and root rot in woody trees of the savanna and semi-desert vegetation of the world. However, the numbers of these parasitic fungi on woody trees were relatively low or small considering the tree population on the two campuses. The presence of these parasitic basidiomycetes might be due to the dispersal of spores from affected plant to healthy wounded plants. However, it is worth noting that wood and root rot basidiomycetes can gradually reduce the tree population of any ecological system or niche. Mohammed et al. (2007) showed that many basidiomycetes serve as important ecological role as wood decomposers as a result of which they causes reduction in the timber yield of most savanna and desert trees. Wood - rotting basidiomycetes are common disease fungi in a large number of 
conifers, deciduous trees, shrubs and hardwoods throughout the forest areas of Arizona. Large losses of timber on living and harvested trees are caused annually by theses fungi (P.D.P., 2011; Uno et al., 2008; Zoberi, 1972). Therefore, wood rotting basidiomycetes are a threat to the savanna tree vegetation and, as a consequence, a threat to the ecological balance. Therefore, if these parasitic basidiomycetes are left unchecked, they may proliferate and become a big problem that may result into reduction in the number of trees in this region.

Table 1: Distribution and Relative Abundances of wood rot parasitic Homobasidiomycetes on Woody trees in Bayero University, Kano

\begin{tabular}{llcc}
\hline Location & $\begin{array}{l}\text { Name of parasitic } \\
\text { Basidiomycetes }\end{array}$ & Number of occurrence & $\begin{array}{l}\text { Relative } \\
\text { abundance (\%) }\end{array}$ \\
\hline BUK old campus & Ganoderma phillipii & 38.8 \\
& $\begin{array}{l}\text { Phellinus noxious } \\
\text { Sub-total }\end{array}$ & 71 & 30.1 \\
BUK new campus & Ganoderma phillipii & 15 & 68.9 \\
& Phellinus noxious & 17 & 14.6 \\
Total & Sub total & 32 & 16.5 \\
Mean & & 103 & 31.1 \\
t-calculated & & 25.75 & 100.00 \\
T-table $(\mathrm{P} \leq 0.05)$ & & 3.27 & \\
\hline
\end{tabular}

Table 2: Number and distribution of tree plant species and parasitic basidiomycetes obtained on the trees

\begin{tabular}{llcc}
\hline Location & Tree Plant species & $\begin{array}{c}\text { Number of } \\
\text { occurrence }\end{array}$ & $\begin{array}{c}\text { Number of } \\
\text { Parasitic } \\
\text { Basidiomycetes }\end{array}$ \\
BUK old campus & Azadirachta indica & 220 & 61 \\
& Parkia biglobosa & 15 & 10 \\
& Mangifera indica & 03 & 00 \\
& Acacia nilotica & 02 & 00 \\
BUK new campus from trees: & 71 \\
& Sub- total & 240 & 25 \\
& Azadirachta indica & 280 & 06 \\
Total & Parkia biglobosa & 94 & 01 \\
\hline
\end{tabular}

Table 3: Extent of damage by parasitic basidiomycetes on woody trees in Bayero University, Kano

\begin{tabular}{|c|c|c|c|c|c|c|c|}
\hline \multicolumn{2}{|c|}{ Location } & \multirow{2}{*}{$\begin{array}{c}\begin{array}{c}\text { Tree } \\
\text { plant }\end{array} \\
\text { Neem }\end{array}$} & \multicolumn{2}{|c|}{$\begin{array}{c}\text { No. of tree } \\
\text { plant }\end{array}$} & \multicolumn{3}{|c|}{$\begin{array}{l}\text { Extent of damage done on tree plant by parasitic } \\
\text { Basidiomycetes }\end{array}$} \\
\hline BUK & old & & 220 & 04 & 00 & 10 & 206 \\
\hline & & Parkia & 15 & 03 & 00 & 10 & 02 \\
\hline & & Mango & 03 & 00 & 00 & 00 & 03 \\
\hline & & Acacia & 02 & 00 & 00 & 00 & 02 \\
\hline & & Sub- total & 240 & 07 & 00 & 20 & 213 \\
\hline \multirow{4}{*}{$\begin{array}{l}\text { BUK } \\
\text { campus }\end{array}$} & new & Neem & 280 & 05 & 00 & 15 & 260 \\
\hline & & Parkia & 94 & 10 & 00 & 10 & 74 \\
\hline & & Mango & 04 & 00 & 00 & 00 & 04 \\
\hline & & $\begin{array}{l}\text { Sub - } \\
\text { total }\end{array}$ & 378 & 15 & 00 & 25 & 338 \\
\hline Total & & 618 & 22 & 00 & 45 & 551 & \\
\hline
\end{tabular}


Bajopas Volume 5 Number 2 December, 2012

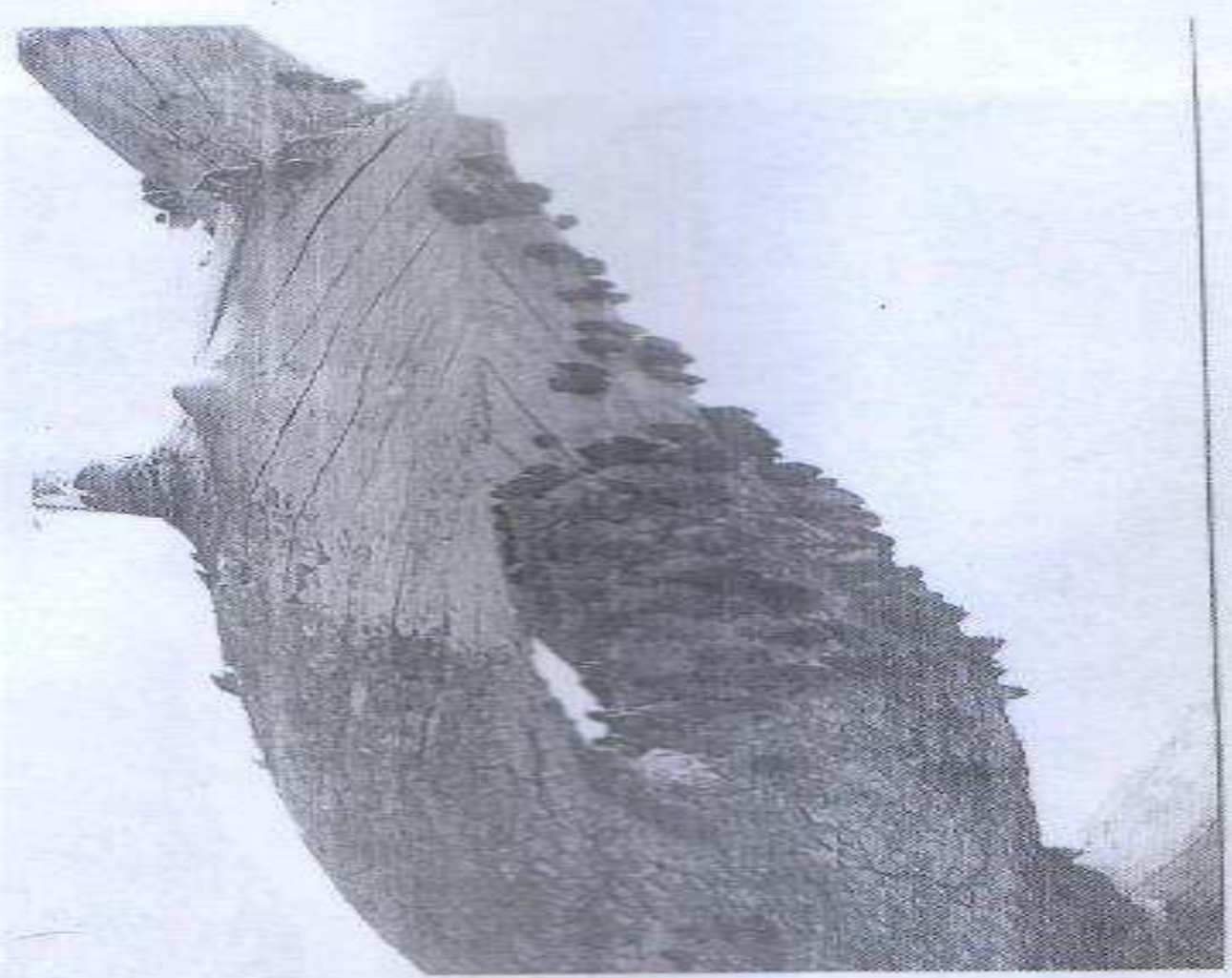

Figure 1. Mood rot causing Phellinus maxious on Acacia nilofica tree

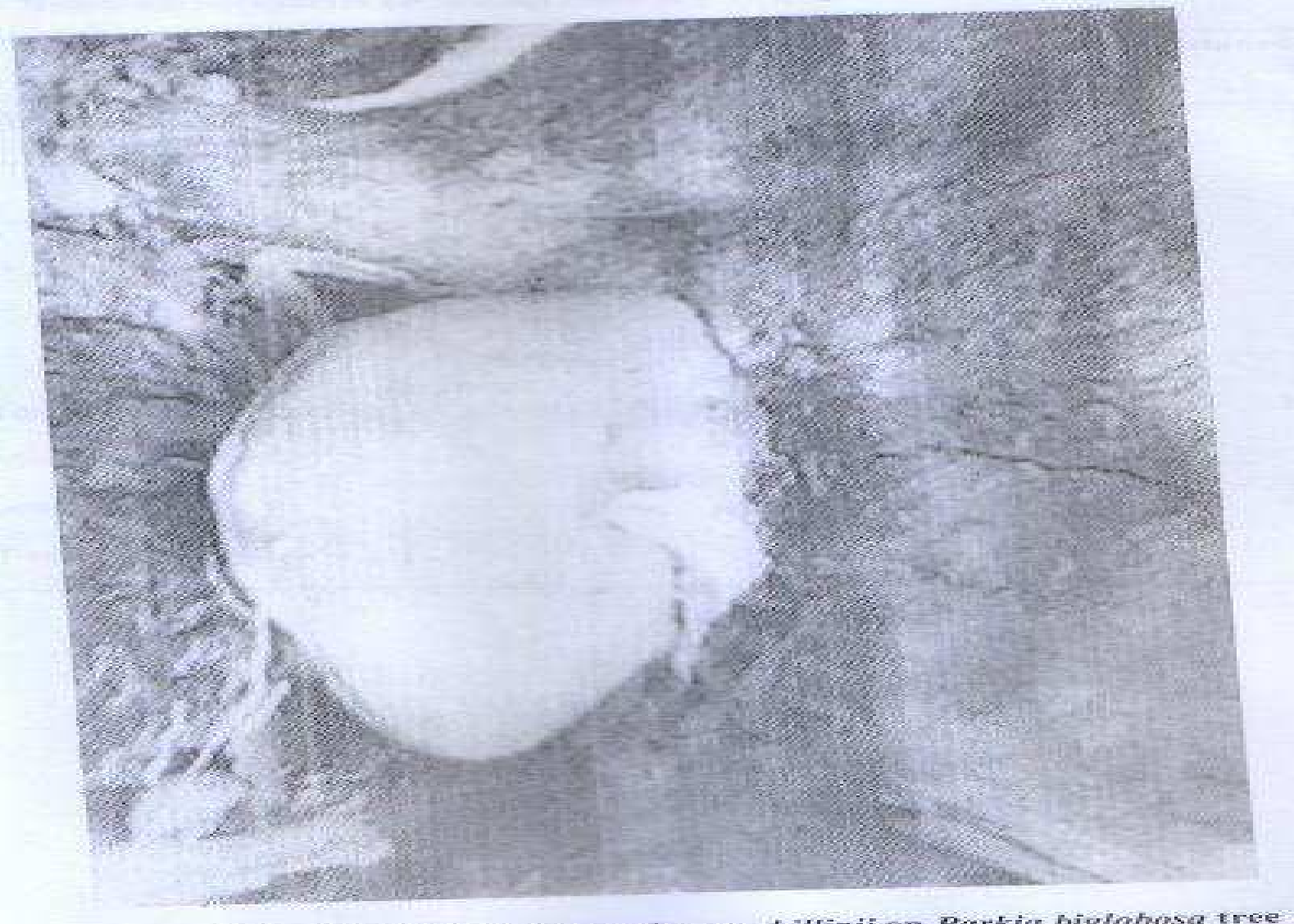

Eigure? Root not causing Garnodernud phillipii an Parkia biglabusa tree 


\section{CONCLUSION}

Parasitic basidiomycetas were responsible for the death of some trees on the campuses of Bayero University, Kano. Therefore, effort should be made to

\section{REFERENCES}

Corner, E,J.H. (2001): The Agaric general Lentinus, Pannus and Pleurotus with particular reference to Malaysian species, Belhefte Zur Nova Hedwigia 69: - 169

Gadgil, P.D. (2005): Fungi on trees and shrubs in New Zealand. Fungi of Zealand, volume 4. Fungal diversity research series 16 . Hong Kong, Fungal diversity press, 437P

Hood, I.A. (2003): An introduction to fungi in queensland, Armidale, Australia, University of New England, School of Environmental Sciences and natural resources management, $388 \mathrm{p}$

Hood, 1.A (2006): The mycology of Basidiomycetes. Heart rot and root rot of Tropical Acacia plantations. Proceedings of a workshop help at Yogyakarta, Indonesia. 7.9 February. 2006.

Kutama, A.S. (2011): Fungi and the services they render to man and the Ecosystem. The green world magazine. Maiden edition. Pp $07-08$

Mehrotra, R.S and Aggarwal, A. (20003): Plant pathology, Second edition. Tata McGraw Hill Publishing company Limited. Pp. 411 423

Mohammed, S.M., Monclavo, J.M. and Ryvarden, L. (1997): A Nomenclatural study of the Ganodermataceae Donk. Synopsis Fungorum 11:1-114 osco Norway fungiflora. stop these wood and root rot basidiomycetes from further killing more of these healthy trees, considering the importance of tress to humanity in general.

Moore, H. (2006): Basidiomycotina classification. Blackwell science publishers Limited. Ram Nagar. India

Norman, R. Randy, R., Captan, R. and Kirk, O. (2008): Comparative study of The basidiomycetes. Blackwell science publishers limited, Ram Nagar, India Pp213 232

Nunez, M, and Ryvarden, L. (2005): Polyporus basidiomycotian and related genera. Synopsis fungorum 10:1-81, Norway Fungiflora

Old, K.M.: Lee, S.S, Sharma, J. and Yuan. Z.Q. (2000): Manual of disease of Tropical Acacias in Australia, South - east asia and India, Jakarta, Indonesia, Center for international Forestry Research. 104p

P.D.P. (2011): Plant disease publications. Disease of urban plants, Cooperative extension college of Agriculture and life sciences. The University of Arizona

Steyaert, R.L. (1967): Les Ganoderma palmmicoles bulletin ju jardin. Botanique Natural de Belgique, 37.:465-497

Tarr, S.AJ. (1962): Diseases of Sorghum, Sudan grass and Brown corn. Commonwealth Mycological institute, Kew. Survey Pp171 - 247

Uno, G: Richards, S. and Randy, M. (2008): principles of botany. The Mc Graw Hills Publishing company, pp $123-145$

Zoberi, M,H. (1972): Tropical macrofungi: some common species. London, Basingstoke. Macmillan, 158p 